Article

\title{
Equal Opportunities in Academic Careers? How Mid-Career Scientists at ETH Zurich Evaluate the Impact of Their Gender and Age
}

\author{
Ralph Hansmann ${ }^{1, *(1)}$ and Dagmar Schröter ${ }^{2}$ \\ 1 ETH Zurich, Department of Environmental Systems Science (D-USYS), Transdisciplinarity Lab (TdLab), \\ Universitätstrasse 22, CHN K 76.2, CH-8092 Zurich, Switzerland \\ 2 ETH Zürich, Department of Environmental Systems Science (D-USYS), Forest Ecology \& Transdisciplinarity \\ Lab (TdLab), Universitätsstr. 22, CHN K 76.2, CH-8092 Zürich, Switzerland; dagmar.schroeter@usys.ethz.ch \\ * Correspondence: ralph.hansmann@env.ethz.ch; Tel.: +41-44-632-36-47 or +41-76-201-77-51
}

Received: 21 July 2018; Accepted: 15 September 2018; Published: 19 September 2018

\begin{abstract}
Gender equality is essential to social justice and sustainable development in the higher education sector. An important aspect thereof is to promote equal opportunities for academic careers. This study investigates the current situation and possibilities for improvement in this regard from the perspectives of mid-career scientists in a sustainability-oriented university department. A survey of scientists from the postdoctoral to adjunct professor level $(\mathrm{N}=82)$ in the Department of Environmental Systems Science (D-USYS) of ETH Zurich (Swiss Federal Institute of Technology Zurich) was thus conducted to investigate judgements, experiences, and ideas for improvement concerning equal career opportunities. About $90 \%$ of the respondents perceived no disadvantages based on gender, ethnicity, race, or faith. However, about $30 \%$ felt disadvantaged due to their age. Comments revealed not a single case in which latter disadvantages were based on prejudice. Instead, ETH-wide or national age and time-based restrictions for certain positions caused the inequality perceptions. Furthermore, comments indicated that these restrictions can disadvantage scientists taking care of children. Some participants suggested a revision or removal of corresponding rules. Further suggestions included an improved availability of childcare places. ETH Zurich recently undertook great efforts to provide excellent and affordable childcare services, increasing the number of available places by about $30 \%$ in the year following this survey.
\end{abstract}

Keywords: equal opportunities; academic career; sustainable development; gender; age; discrimination; leaky pipeline

\section{Introduction}

Creating equal opportunities for people of different genders, races, nationalities, and ages represents a crucial goal of sustainable development in a society, as it includes justice regarding the possibilities of humans to satisfy their needs [1]. The higher education sector is taking a leading role for society's transition towards sustainable development, and should therefore be in the vanguard for creating equal opportunities as it is for other facets of sustainability [2-6]. However, barriers to women in science remain common worldwide, despite efforts at levelling the playing field [7-12].

In Switzerland, a Federal Equal Opportunity at Universities Program was launched in 2000 and has since been continued through various phases. The main foci of the program are gender equality and work-family-life balance; similar to other European countries also in Switzerland women are underrepresented in high academic positions. Thus, a long-term goal of the program is to prevent a loss of talent $[13,14]$. The Swiss Equal Opportunity Program included (i) an incentive (sub-)program 
for the promotion of female professors; (ii) a mentoring program for the promotion of female junior researchers; and (iii) a work-life program for greater balance between academic career and family, which prompted all of the Swiss universities to introduce childcare measures and take an additional focus on fostering support for dual-career couples at Swiss universities. Recently, an additional subprogram; (iv) "Gender Studies", was included that aimed to establish this field as a scientific discipline at Swiss universities. In response to this program, the Swiss Universities developed action plans, and positive trends on gender equality were observed since the start of the program [15-17].

For example, to increase the compatibility between work and family, in 2014, ETH Zurich (Swiss Federal Institute of Technology Zurich) introduced new possibilities for financial support for bearing the costs of childcare services and founded an internal service subdivision, "Hello Kids!", to support families with young children in an encompassing way by providing consultancy services, helping in the procurement of childcare services, and assisting in the access of financial support [18].

However, women remain underrepresented in higher academic positions, even though the share of females among the graduates of Master's and comparable programs in Switzerland has more than doubled during the last 40 years, and is now at approximately 50\% [19]. The number of doctorates completed at Swiss universities continuously increased from 3320 in 2008 to 4151 in 2017, and the percentage of doctorates completed by females continuously increased from $41.3 \%$ to $44.8 \%$ during that period [20]. However, among the 3500 professorships at Swiss universities, only about $20 \%$ were held by female professors in 2016 [21], and the share of females among newly appointed professors was approximately $33 \%$, still far from a $50 \%$ ratio.

The scientific community is faced with a well-documented phenomenon dubbed "leaky pipeline" [22], which means that high drop-out rates of women at each step of the job ladder in academic careers, particularly in the steps beyond postdoc, lead to a decline in the share of females with increasing positions.

Does the leaky pipeline phenomenon exist at ETH Zurich, a technology-oriented university with a share of $30.6 \%$ female students in 2016? A comparison of shares of women at increasingly senior career levels shows that it does: females constitute $31.2 \%$ of the doctoral candidates, $28.5 \%$ of the candidates on the postdoctoral level, $23.9 \%$ on the senior scientific assistant level, $14.9 \%$ of senior scientists, and $13.5 \%$ of professors [23]. These numbers refer to the average situation at ETH Zurich. However, there are, differences among its 16 departments as the percentages of female students range from $10.2 \%$ in the Department of Mechanical and Process Engineering (D-MAVT) and three further departments with less than $20 \%$ females (e.g., Department of Computer Science, Department of Information Technology and Electrical Engineering, and the Department of Physics) to slightly more than 50\% in the Department of Biology and in the ETH Department of Environmental Systems Science (D-USYS) to 63.5\% females in the Department of Health Sciences and Technology (D-HEST) [23].

The ETH Department of Environmental Systems Science (D-USYS)—where our study was conducted - has a considerably higher than average proportion of female students for ETH, with $54.4 \%$ in 2016. This may be due to the multi, inter, and transdisciplinary sustainability orientation of the study programs that D-USYS offers (Bachelor's and Master's degree programs in both Agricultural Sciences and Environmental Sciences), which take a systemic view on environmental systems and human-environment systems and comprise, next to education in natural sciences, also education in social sciences, environmental policy, and economics. Having the second highest percentage of female students among 16 departments, D-USYS cannot be regarded as representative for ETH Zurich. However, the dedicated sustainability orientation of the D-USYS mission, research, and teaching may be connected to a high sensitivity of its members, also in relation to the sustainability aspects of internal processes. The proportions of women on sequential career levels decrease at D-USYS from $48 \%$ on the doctoral candidate and postdoctoral levels, to $39 \%$ at the senior scientific assistant level, to $15 \%$ among female senior scientists, and 16\% female professors overall in 2015 [24].

The factors causing the "leaky pipeline" phenomenon are not yet fully understood. It is likely a combination of traditional social roles, difficulties with reconciling work and family life, 
a reduced integration of women in professional academic networks, the lower career ambitions of women compared to men, and less self-confidence in their own academic capabilities $[9,25,26]$. Other contributing factors are negative biases in the perception of female applications [27-29], better working conditions for men as compared to females at universities [12,30,31], and a high workload of females with academic service activities negatively impacting research productivity [32].

A study based on Swiss data confirmed that the reconciliation of family and work-especially with the birth of a child directly after the doctorate-is a factor, which tends to disadvantage women in the development of their academic career, and also identified the poorer integration of emerging female researchers in international academic networks as an important interrelated and contributing factor [19]. Mentoring strategies have been applied to increase self-confidence of female researchers and enhance their embedding in scientific networks to support their careers, but gender imbalances still exist $[9,14,25,26]$.

A global comparison of female-to-male ratios of papers published by country shows that Switzerland is in company with Austria and Germany at the lower end [11]. The authors of the latter study caution against simplistic explanations, but point to connections between gender issues and age discrimination, which are often subtle. They encourage institutions to analyse their local micromechanisms within the social, cultural, economic, and political contexts. Various studies show and explain how ageism and gender issues are related to each other [33-37]. However, apparently age-related stereotypes, generalisations, and discrimination have not caused the same public attention and academic attention as sexism or racism. Instead, age prejudice is to a considerable extent socially condoned, and even institutionalised [38]. The empirical basis on processes of age-related discrimination seems still underdeveloped, and the impact is under-reported [37,39]. Age discrimination mostly affects elder people, and may bear psychological, social, and economic costs for them, for example if they are not promoted or disadvantaged in an application process because of their age. There may also be negative macroeconomic impacts. According to Grossman [39], "society's lack of concern for this type of discrimination may prove more costly in the future as employers look more to older workers to fill projected workforce gaps (p. 71)".

An important aspect that merits attention in this regard is the formal age and time-based rules and restrictions on certain positions and/or career opportunities. Such formal limitations can in principle concern all people in certain phases of their lifespan and career path, which lends them a neutral appearance. However, they may nevertheless produce inequality, for example, if they favour people with "traditional" highly focussed career paths. A continuing dominance of masculine values and practices within the academic system, including aspects such as strong hierarchies and high competitiveness, has been criticized by various scholars [40-42]. Time and age-based rules that have been developed in the context of such values could pose a disadvantage to the increasing number of people with a higher diversity of life, responsibilities, and occupations. For example, people with a significant dedication to volunteer work and social service, sports, or other aspirations, or gave birth to children, helped to raise children, or took care of other dependents or people with health problems, may be discriminated against by time or age-based limitations if they are not designed with foresight. Even though much progress has been made, traditional social norms associating women with family and childcare are to some extent still operative in higher education institutions, and make it difficult to combine being a mother with advancement in the academic career [43]. Time and age-based rules may be one aspect perpetuating this problem.

In particular, in an academic setting, such age and time-based restrictions seem widespread. For example, at ETH Zurich, there is a 35-year rule for assistant professors and two six-year rules for other scientific staff $[44,45]$. Assistant professorships are usually not granted to persons older than 35 years at ETH Zurich. Exceptions from this rule can only be made if the applicant has (a) considerable industrial experience, or (b) served in the military for longer than usual, and/or if (c) his or her career has been delayed by parenthood. In addition, the upper age limit can be raised to 37 years in the 
case of extraordinary qualification of the applicant [45], but under such circumstances, applicants will normally be directly employed as tenured professors.

Temporal working contracts at the $\mathrm{PhD}$ / postdoctoral levels at ETH are restricted to a maximum of total six years, and temporal contracts at the senior scientific assistant/senior scientist levels are likewise restricted to a maximum of six years. These six-year rules have been summarized in a school-specific ordinance in 2001 as a result of a broad discussion within ETH Zurich about academic careers [44]. Together, both rules rule form a kind of 12-year rule, since exceptional prolongations granted for the first six years are subtracted from the potential duration of the second six-year period as a senior scientific assistant.

At the postdoctoral level, no open-ended contracts are offered, and only few permanent senior scientist positions are available. The situation at ETH Zurich is similar to other Swiss universities in this regard. A number of scientists have criticised that the Swiss academic system currently offers not enough open-ended positions apart from full professorships, which renders academic "Mittelbau" positions unattractive and even risky for a career, possibly impeding the scientific education of current and future generations [46-48]. According to a study by the State Secretariat for Education, Research, and Innovation, the provision of more open-ended contracts is as a major concern of Swiss mid-career scientists [15]. According to the survey, only $28 \%$ of the scientists with a completed doctorate working at Swiss universities (excluding professors) have an open-ended contract. The percentage among female scientists is about $20 \%$, and is even lower than among males, with approximately $33 \%$ open-ended positions [15]. Among those still working in academia five years after their doctorate, $55 \%$ have time-limited contracts, $30 \%$ have open-ended contracts as scientists or lecturers, and $15 \%$ obtained a professorship. Half of these professorships were obtained outside Switzerland, 25\% were obtained at Swiss universities and a further $25 \%$ were obtained at Swiss universities of applied sciences and elsewhere [21].

At D-USYS, there are currently 35 full professors, nine assistant professors, and 36 senior scientists with permanent contracts. However, there are more scientists with time-limited contracts, among them about 180 persons with completed doctorates (including 118 postdocs) and 255 scientists without completed doctorates (including 209 ongoing doctorates). Tenured ETH professors may typically employ not more than one senior scientist on an open-ended contract. Exceptions from this rule can be granted for certain professors and within certain departments, but of course, such exceptions need to be in line with financial constraints. For the access to the rare and timely unlimited positions, scientific excellence and employability are important, but age factors can play a role, as professors are only allowed to provide open-ended contracts to scientists who are considerably younger than they are themselves if the concerned ETH department commits to a long-term career development as an independent scientist, which includes commitment to funding the person beyond the retirement of the professor. Similar age rules also exist at other Swiss universities and in other countries. For example, in Germany, the position of a full professorship represents an official state position that can only be obtained up to a certain age, with the exact age limit varying between the federal states in the range from 45 years in Baden-Württemberg to 55 years in the federal states of Saarland and Bremen [49].

Apart from gender and age issues, further aspects of equal opportunities in science careers include possible disadvantages due to race, nationality, and faith. Indications of prejudice and other barriers to equal opportunities at higher education institutions based on ethnic and cultural aspects have been found in various studies [50,51].

On the outlined background, the present study investigates the perception of important aspects of equal opportunities among scientists working in the Department of Environmental Systems Science (D-USYS) at ETH Zurich regarding gender and family situations, as well as national, ethnic, religious, racial, and age-related factors. Thus, this study aims to improve the understanding of how existing structures work at this particular workplace, and of the resulting actual conditions in relation to equal opportunities. 
D-USYS conducts research and teaching with a strong orientation towards sustainability. The department's activities thus include research on environmental systems and their relevance to society as well as training future generations of scientists and sustainability-oriented decision-makers in society, industry, and politics. Research into the professions of the graduates indeed showed that they enter a broad range of professional domains such as research institutes and universities, environmental planning and engineering companies, trade and insurance companies, public administration and environmental non-governmental organisations (NGOs), and that they have a considerable sustainability outreach through their activities [52,53]. Consistent with its mission, the department aims to be in the vanguard of sustainable development also regarding internal processes. In line with this aspiration, the study presented here was commissioned by the department leadership.

\section{Materials and Methods}

\subsection{Survey among Advanced Academics Working at D-USYS}

A survey was conducted among scientists within D-USYS who form part of the so-called academic "Mittelbau", which is a term used in Germany, Austria, and Switzerland to denote the graduated academic staff below the professorial level, with minor differences between these countries in the exact definition of the term. In Switzerland, the Mittelbau includes graduated persons working in a broad range of positions ranging from doctoral students, via scientific assistants and postdoc, to senior scientific assistants, senior scientists, titular professors, and also includes assistant professors [54]. The focus of the study was on scientists who already have advanced considerably on their academic career path, and have long-time experience and insight into working-life at D-USYS. Therefore, the survey exclusively targeted scientists who have already completed a doctorate or PhD (at D-USYS or elsewhere), and after its completion have been working for at least one year in the department. We refer to such scientists as "Mittelbau" here (though advanced Mittelbau would be more precise). Strategic research foci across the department's professorships, in which these mid-career scientists work, include climate change, food security, sustainable resource use, biological diversity, as well as adaptation and ecosystem processes and services [55], and in addition, their scientific activities focus diverse further sustainability-oriented research topics. They also contribute substantially to teaching in the degree programs that D-USYS offers.

Opinions, judgments, experiences, and ideas that are relevant to equal career opportunities were collected within an online survey that covered various aspects of work-life including the current position, tasks, and responsibilities as well as career perspectives and goals of the participants. The overall survey was comprised of 53 items in total, including open-ended and closed-ended questions. The first two items aimed to identify whether the responder belonged to the targeted group (see above). Thereafter, the main part addressed academic background, employment history, current tasks and responsibilities, and career planning, as well as aspects impacting equal opportunities with regard to gender, age, ethnic, religious, and family aspects. Subsequently, ideas were invited for improving work-life in general terms and ensuring equal career opportunities for employees with and without children or other dependents. Finally, demographic information (gender, age, nationality) was elicited.

The present article does not cover the entire questionnaire, but focusses on items related to equal opportunities. This includes first and foremost the specific questions addressing this issue directly as described in the following.

Participants were asked: "Do you feel that you are in any way disadvantaged at D-USYS due to gender, ethnicity, race, or faith?" The possible responses to this question were "yes", "rather yes", "rather no", "no", and "I don't know". These responses were coded as a four-point rating scale, from "yes" (=1) to "no" (=4), but the answer "I don't know" was considered apart from this scale. An additional, open-ended question asked for comments to explain their own rating. Furthermore, the participants were asked: "Do you feel in any way disadvantaged at D-USYS due to age?" Here, the 
possible responses were "yes", "no", and "I don't know". Those answering with "yes" were asked to provide a comment explaining the disadvantages that they perceived.

To investigate the equal opportunities of parents with young children as well as people who have to take care of other dependents, a filter question asked: "Do you have children or other dependents (e.g., elderly relatives etc.) that need taking care of in your household?" The possible responses were "yes, children", "yes, other dependents", and "no". Those responding with "yes" were addressed in an open-ended format by the additional item: "Did having children or other dependents in your household change your career path? If so, please specify." Furthermore, all participants were asked about possibilities for improving equal opportunities through the question "Could D-USYS or ETH do more to ensure equal career opportunities for employees with and without children or other dependents?" The possible responses were "yes", "no", and "I don't know", and a further open-ended question asked for corresponding suggestions or comments.

\subsection{Recruitment and Number of Participants}

The survey invitation was sent out on 5 November 2015 to 489 email addresses from a corresponding list containing all of the current members of the total D-USYS Mittelbau and technical staff. The survey was open from then on till 28 December 2015. In total, 156 members of D-USYS visited the online survey and responded to the first question. A majority of $62 \%$ of them had a doctorate (PhD) degree. These 96 persons were further asked whether they had been working at D-USYS for at least one year since the completion of the $\mathrm{PhD} /$ doctorate. The 82 who answered with "yes" therefore belonged to the target group at which the survey was directed ( $86 \%$ of 95 respondents to the second question).

All members of the target group responded to the survey, so that the maximum sample size available for the reported analyses was $\mathrm{N}=82$ (although the number of responses varies slightly between items). For some items, it was obligatory to respond in order to be able to proceed further with the survey, but for most items, responding was not defined as obligatory. For example, responses were not obligatory for the items on gender and nationality, as some people may not wish to respond to this on diverse grounds. Answering open-ended questions was likewise not defined as obligatory to prevent drop-outs and allow smooth proceeding through the questionnaire. Of the participants from the target group, 77 completed the whole questionnaire up to the last obligatory item "year of birth" (i.e., age after transformation for statistical analysis and reporting). The drop-out rate was thus $6 \%$, which is very low in light of the considerable length and number of questions and sub-questions that the survey contained. Completing the survey took on average $26.6 \mathrm{~min}(\mathrm{SD}=12.8$, median $=22.5$, mode $=20$ ), with a range from $10 \mathrm{~min}$ to $59 \mathrm{~min}$.

\subsection{Demographic Distribution of Participants}

The item asking for the gender of the participants was answered by 77 people. The resulting gender distribution was $58.4 \%$ males, $39.0 \%$ females, and $2.6 \%$ "other". The average age of the participants was 39.3 years ( $\mathrm{SD}=8.3$ ) with a median of 37 years, and a modulus of 35 years (12 persons). Considering persons with single nationalities, the majority of the 72 respondents to the respective question were either German (33.3\%) or Swiss (27.8\%), followed by British, French, and Austrian (with $4.2 \%$ each), and Italian with $2.8 \%$. In addition, some persons had double nationalities: $4.2 \%$ were Swiss and German, and likewise, $4.2 \%$ were Swiss and French. The remaining $15.3 \%$ had nine different single nationalities from six European and three non-European countries, and two had double nationalities.

\section{Results}

\subsection{Perceived Disadvantages Due To Gender, Ethnicity, Race or Faith}

A large majority of $81.8 \%$ of the participants responded with a straight "no" to the question regarding whether they felt disadvantaged at D-USYS due to gender, ethnicity, race, or faith, and a further $7.8 \%$ responded with "rather no" (Figure 1). Still, in total, $9.1 \%$ of the participants responded 
with "yes" (6.5\%) or "rather yes" (2.6\%), and 1.3\% responded with "I do not know". When considering the responses as ratings on a four point-scale $(1=$ no, $2=$ rather no, $3=$ rather yes, $4=$ yes; excluding the one person responding "I don't know") the average rating of the Mittelbau members was with $\mathrm{M}=1.3$ $(\mathrm{SD}=0.8)$ only slightly above "no". However, the average rating of the females was with $\mathrm{M}=1.7$ $(\mathrm{SD}=1.2)$, which was significantly higher than that of the males with $\mathrm{M}=1.0(\mathrm{SD}=0.2$; Mann-Whitney U-Test $p<0.001$ ), reflecting more perceived disadvantages among females as compared to males.

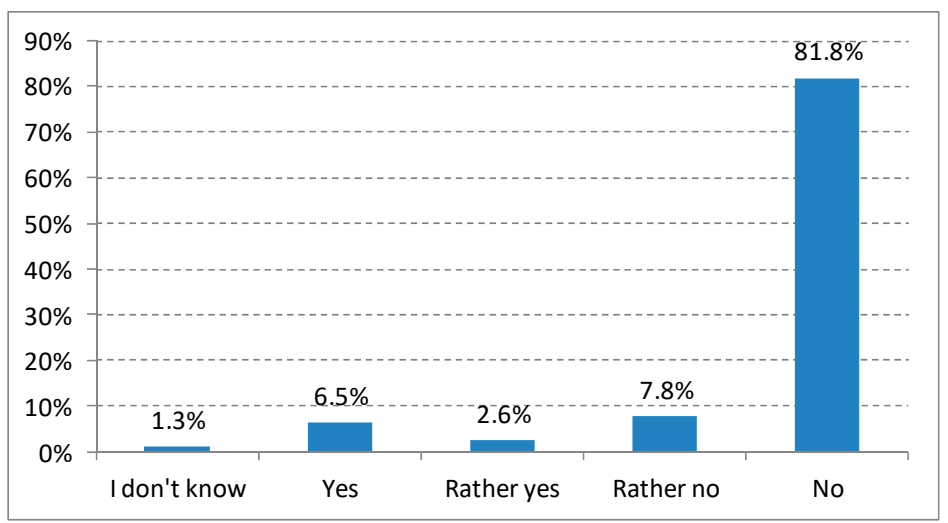

Figure 1. Do you feel that you are in any way disadvantaged in the Department of Environmental Systems Science (D-USYS) due to gender, ethnicity, race or faith? $(\mathrm{N}=77)$.

Only 13 participants commented on their response (Table 1). Among them, seven had responded with "no" and four had responded with "yes", so those perceiving inequality were more inclined to give detailed comments. Various comments from participants who responded "yes" spoke of gender inequality (Table 1, comments \#1-4). A male participant who responded "no", since the question asked if he felt disadvantaged due to gender, nevertheless perceived gender-based inequalities (comment \#8). Two comments on "rather yes" (\#5-6) referred to gender inequality, but additionally raised issues of ethnicity or nationality. Comments \#4 and \#7 pointed to the same issue of a woman's contract continuing when she takes maternity leave, which reduces the maximum contracted time allowing her to do research at ETH Zurich, because of the two sequential six-year rules described in the introduction. Both responses thus point to the distinct relationship between gender and academic or biological age that may result in a competitive disadvantage of females compared to men.

Table 1. Comments of the participants on their responses to the question: "Do you feel that you are in any way disadvantaged at D-USYS due to gender, ethnicity, race, or faith?" ${ }^{1}$.

\section{Comments on "Yes"}

As a woman, and as the spouse of a professor, I sometimes run into weird expectations, such that people

1 are unaware of my own achievements and my genuine skills that justify my being here. Meeting times are not family-friendly.

2 Indirectly, being a woman at this age in research brings an undeniable conflict between family plans and career, which can be overwhelming. Support here is still unsatisfactory.

3 Men have better conditions than I have, especially regarding the rate of employment compared to workload.

My maternity leave lasted four months, after which I resumed 100\%; nonetheless, I am disadvantaged

4 compared to my male colleagues, because my contract cannot be prolonged for this period. But it is not my fault that I am female, the gender that gives birth.

Comments on "Rather yes"

5 There is a subtle aggressiveness towards women and German people.

6 Sadly, I think ethnicity plays a role, and gender too, even if less than ethnicity. 
Table 1. Cont.

Comments on "Yes"

7 During my maternity leave, my contract continued, in other words, my maximum time at D-USYS is four months shorter than for people who did not take maternity leave.

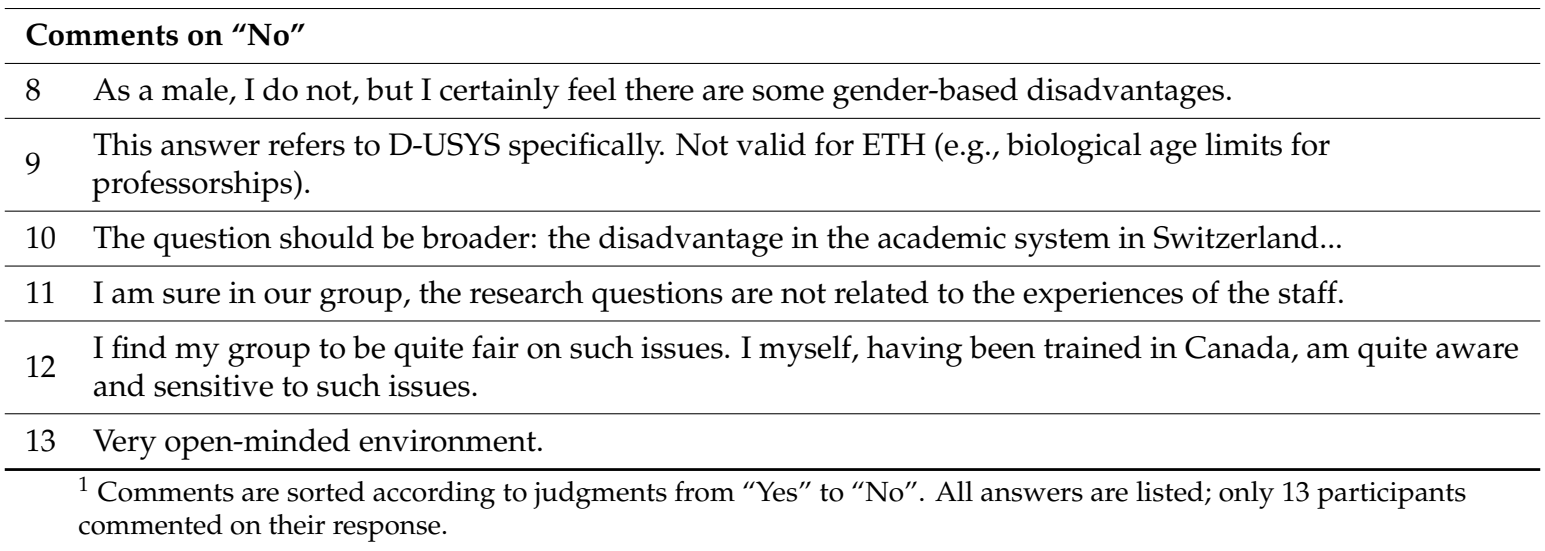

Some comments of those who responded with "no" to the question of perceived disadvantages nevertheless mention corresponding issues. For example, comment \#9 criticises biological age limits at ETH Zurich in general, and comment \#10 hints to the even broader context of inequalities within the entire "Swiss academic system". So, both respondents refused to attribute existing inequalities to D-USYS, presumably recognising that D-USYS is legally required to apply the rules defined on higher levels. Finally, there are three purely positive comments, stressing the perception that D-USYS is a non-discriminatory environment (comments \#11-13).

\subsection{Perceived Disadvantages Due To Age}

There exist various age limitations for career steps in the Swiss academic system based on academic age or biological age. Therefore, the question, "Do you feel in any way disadvantaged at D-USYS due to age?" was specifically asked in the survey. A clear majority of $61 \%$ did not feel disadvantaged because of their age. However, a substantial share of just under $30 \%$ of the respondents answered with "yes", while a further 9.1\% were unsure and replied, "I do not know" (Figure 2). Among women, the percentage of "yes" responses was 33.3\%, which was not significantly higher than among males with $26.7 \%$ (Chi-square test, $\mathrm{df}=1, p=0.461$ ).

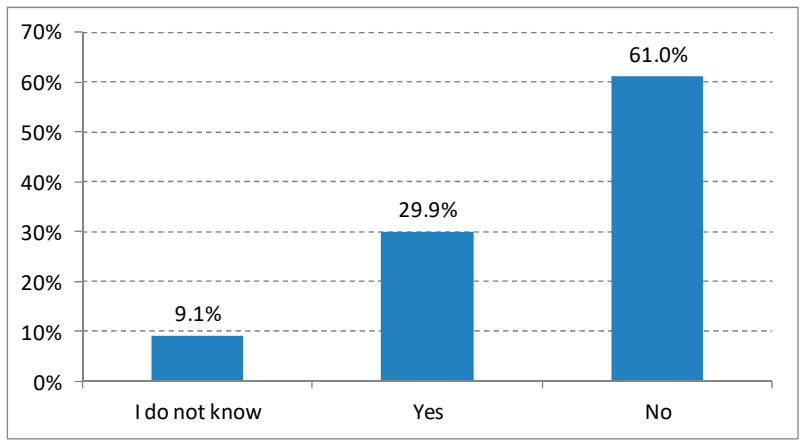

Figure 2. Do you feel in any way disadvantaged at D-USYS due to age? ( $\mathrm{N}=77)$.

The comments provided by those responding with "yes" are listed in Table 2. They show that feeling disadvantaged based on academic and biological age is an important topic in D-USYS, and hence presumably in the Swiss University system as a whole, since the age-based rules are predefined on the national level. Twelve of the comments directly mention the 35-year-rule [45], i.e., the age limit for becoming an assistant professor at ETH (comments \#1-12, Table 2), possibly recognising 
that the specific exceptions that have been defined within this rule will not be applicable to them. Comments \#13-15 criticise the six-year rules, which limit the duration of $\mathrm{PhD}$, postdoc, and similar positions as well as those of (non-permanent) senior scientific assistants and similar employments [44]. Two of these comments link these rules to disadvantages for scientists with children (or illness, or other dependents, e.g., comments \#14 and \#15). Comments \#17 and \#18 criticise an age-related custom at ETH Zurich that disadvantages researchers who are considerably (typically more five years or more) younger than their employing professor, namely that open-ended employments are only granted to such scientists under the precondition that the concerned ETH department can ensure their scientific perspective, including financing also for the time after the professor has retired. Various responses doubt that age and time limits serve scientific quality or the institution as a whole. Comment \#16 states that the issue of age discrimination is not addressed at USYS, but it should be.

Table 2. Comments of the participants feeling disadvantaged at D-USYS due to age ${ }^{1}$.

\begin{tabular}{|c|c|}
\hline Number & Response \\
\hline 1 & 35-year age limit for assistant professors. \\
\hline 2 & As I started my PhD late, I am unable to apply for assistant professor or professor positions at ETH. \\
\hline 3 & I see the age limit of 35 to become an assistant professor as a great career hindrance. \\
\hline 4 & Cannot become (junior) professor here since I am older than 35 . \\
\hline 5 & I am over 35 so I feel like I am worthless according to the ETH hiring scheme. \\
\hline 6 & $\begin{array}{l}\text { I decided not to apply for ERC grants (European Research Council grants) because I was } 36 \text {. Age } \\
\text { limits (35) to get a position of assistant professor at ETH was the reason. I am not sure that the age- } \\
\text { based discrimination has a robust motivation behind it. }\end{array}$ \\
\hline 7 & $\begin{array}{l}\text { I had a career before I became an academic and certainly feel that my age (not my academic age) has } \\
\text { been a serious disadvantage; for example, I would be too old to apply for assistant professorships. }\end{array}$ \\
\hline 8 & $\begin{array}{l}\text { I was thinking about applying for a SNF (Swiss National Science Foundation) professorship. I was } \\
\text { not restricted by age from SNF, but from ETH, because I would need to be not older than } 35 \text {. }\end{array}$ \\
\hline 9 & No chance to become assistant professor. \\
\hline 10 & $\begin{array}{l}\text { The ETH regulations on age ( } 35 \text { years for asst. prof.) prevent me from applying for ERC grants. The } \\
\text { six-year constraint makes it practically impossible to attract external funds, as I am unlikely to be } \\
\text { allowed to stay until the project ends. }\end{array}$ \\
\hline 11 & Too old for becoming an assistant professor at ETH with own funding (e.g., ERC or SNF). \\
\hline 12 & $\begin{array}{l}\text { Employment regulations do not allow becoming permanent beyond a certain age limit. The 35-year } \\
\text { rule for becoming an assistant professor does not always reflect personal career paths. }\end{array}$ \\
\hline 13 & $\begin{array}{l}\text { There is no future within the D-USYS that is foreseeable due to the maximum lifetime as postdoc } \\
\text { (six years) or Oberassistent }{ }^{2} \text { (six years). }\end{array}$ \\
\hline 14 & $\begin{array}{l}\text { The age limits at ETH are definitely discouraging and counterproductive. Excellence has nothing to } \\
\text { do with age. I feel that these limits also definitely discriminate researchers with families and } \\
\text { children. }\end{array}$ \\
\hline 15 & $\begin{array}{l}\text { The academic age thing is just as academic-ageist as ageist rules. If you do anything after your } \\
\text { PhD-injury, baby, even time off-then how does that make you a less good researcher than } \\
\text { someone who had an injury/baby/sickness/time off before they completed? }\end{array}$ \\
\hline 16 & $\begin{array}{l}\text { There are age limits on opportunities that I do not understand. Age discrimination is not a topic } \\
\text { here, but it should be. }\end{array}$ \\
\hline 17 & No chance to get a permanent contract due to age difference to professor. \\
\hline 18 & Permanent position not possible due to age difference to professor. \\
\hline 19 & I am "old" and therefore disadvantaged in any kind of hiring process. \\
\hline 20 & At 58 , there is no real career to follow;-) \\
\hline
\end{tabular}




\subsection{Perceived Disadvantages Due To Having Children or Other Dependents}

A total of $44.2 \%$ of the respondents had children (42.9\%) or other dependents (1.3\%) that they needed to take care of at home. These participants were asked whether having children or other dependents changed their career path. Their answers are shown in Table 3.

Table 3. Responses of participants with children or other dependents in their household to the question whether and how this influenced their career path.

\begin{tabular}{|c|c|}
\hline \multicolumn{2}{|c|}{ Comments indicating "No/rather no" } \\
\hline $1-3$ & No/No, not yet/Not yet \\
\hline 4 & $\begin{array}{l}\text { I don't think so. Maybe I don't dedicate as much time to work as I would have otherwise and maybe this } \\
\text { reduces my academic output, and maybe this is the reason why I am not a professor. But I don't think so. }\end{array}$ \\
\hline \multicolumn{2}{|r|}{ Comments indicating "Yes/rather yes" } \\
\hline 5 & $\begin{array}{l}\text { Yes of course!! I moved to Switzerland when we had our first child. It is much harder to move a whole } \\
\text { family just because of your own career. }\end{array}$ \\
\hline 6 & Yes, having a job abroad is much more difficult. \\
\hline 7 & Yes, my decision to permanently stay in Switzerland. \\
\hline 8 & Yes, I work part-time. \\
\hline 9 & $\begin{array}{l}\text { Yes-I reduced my workload to } 80 \% \text { (sometimes } 70 \% \text { ) when the kids were small; this reduced my } \\
\text { potential to compete against } 130 \% \text { devoted applicants for professorial positions, and hence I accepted the } \\
\text { position at ETH that I am having now. }\end{array}$ \\
\hline & $\begin{array}{l}\text { Yes, it did. I do not want to work full-time as long as my kids are smallish. One of my kids in particular } \\
\text { did not agree with caretaking outside of the family very much. He could only be stretched so far with that. }\end{array}$ \\
\hline & $\begin{array}{l}\text { Yes, it slowed down my career and reduced the number of following career steps (e.g., going abroad for a } \\
\text { few months/years, only part-time jobs). }\end{array}$ \\
\hline & $\begin{array}{l}\text { Yes. Less time for work, since family-unfriendly conditions in Switzerland make the balance between } \\
\text { work and private life a constant struggle. }\end{array}$ \\
\hline 13 & In some way, as other factors become more important than work and career. \\
\hline & Yes. I reassessed my priorities and am questioning the validity of staying in an academic career. \\
\hline 15 & Yes. I am seeking a job that allows a better work/life balance. \\
\hline 16 & Yes, without children, I would probably have gone for a professorship, but with them, I did not want to. \\
\hline 17 & Yes, social responsibilities come at a cost: precious time. \\
\hline 18 & Yes, I became very efficient and adaptive: nothing is projectable anyway. \\
\hline & Yes, but not regarding employment at ETH. ${ }^{1}$ \\
\hline
\end{tabular}

Only one comment was a strict "no" (\#1), whereas some responses reflected uncertainty around whether and how children have influenced or will affect their career (comments \#2-4). The people who saw an impact on their careers explained this by reduced mobility (comments \#5-7), reduced time available for work and / or a shift to part-time employment (e.g., comments \#8-12), and shifted priorities when raising children (e.g., comments \#13-15). Many of these respondents thus mentioned conscious shifts in career planning and time management as a consequence of having children.

\subsection{Suggestions for Improving Opportunities of Employees with Children}

When asked whether D-USYS or ETH Zurich as a whole could do more to ensure equal career opportunities for employees with and without children or other dependents, the majority of the participants (53.2\%) responded with "I don't know"; only 6.5\% responded "no", and 40.3\% responded with "yes" (31 respondents). The high percentage of those who said "I don't know" shows a prevalent uncertainty amongst the participants. 
In total, 22 participants commented on what D-USYS and ETH Zurich could do to improve equal opportunities, as listed in Table 4. Various comments expressed concerns about the current accounting of part-time employments and periods of maternity and paternity leave in relation to the two sequential six-year rules, and suggest changes that could make it fairer for employees with children (comments \#1-4). Comment \#1 thus suggests that the six-year rule should be based on the actual work time at ETH Zurich, and not the number of years with a contract, and comment \#2 suggests that the time of maternity leave should be excluded from the six years. Further comments suggested increasing the duration of paternity and maternity leave and introducing the possibility of sharing it between partners, so that the father can have an equal and active role (comments \#7-9). It was also suggested that working part-time should be appreciated by the employer, particularly after the birth of a child (comments \#9-10). One of these comments (\#9) explicitly mentioned the importance of the positive attitude of superiors towards employees becoming parents.

One participant spoke to the issue of working part-time and gaining recognition, expressing that having worked part-time should be taken into account when assessing performance, so that output is measured against required time (comment \#5).

The availability of childcare was mentioned a lot, with people asking for more (comments \#12-15) and more affordable (comments \#12 and 16) and flexible (comment \#17) options. One person criticised the Swiss childcare system in general, feeling that it restricts possibilities for combining family and career (comment \#18). Other issues were the need for flexible working times and more job security (e.g., comments \#11 and \#20-21). Finally, one participant suggested that partner hire positions should be made available not only when professors are hired, but also on the level of hiring senior staff (comment \#22).

Table 4. Suggestions of participants to promote equal career opportunities for employees with and without children/other dependents at ETH Zurich. ${ }^{1}$

\begin{tabular}{|c|c|}
\hline Number & Response \\
\hline 1 & $\begin{array}{l}\text { Allow for part-time being counted towards the six-year limit (e.g., full-time means six years stay, } \\
75 \% \text { working time gives you a max. of eight years, etc.). }\end{array}$ \\
\hline 2 & $\begin{array}{l}\text { The duration of the contract should be prolonged for the period of the maternity and paternity } \\
\text { leave; otherwise, there will be no gender equality at ETH. }\end{array}$ \\
\hline 3 & $\begin{array}{l}\text { The max. contract lengths is six years without taking into account whether you work full-time or } \\
\text { part-time. }\end{array}$ \\
\hline 4 & See my remark about my maternity leave. (cf. Table 1, comment 7 ) \\
\hline 5 & $\begin{array}{l}\text { Recognition of performance should be given in consideration of the level of employment (what did } \\
\text { somebody achieve "in spite" of reduced working hours). }\end{array}$ \\
\hline 6 & $\begin{array}{l}\text { I think permanent academic staff should be given the opportunity to gain recognition for their } \\
\text { academic and teaching achievements, as is the case in most universities. The Mittelbau are } \\
\text { essentially lecturers, senior lecturers, and associated professors. }\end{array}$ \\
\hline 7 & $\begin{array}{l}\text { Being able to share parental leave would be great. It should not necessarily be the mother who can } \\
\text { only take leave. }\end{array}$ \\
\hline 8 & $\begin{array}{l}\text { Increase the parental leave for fathers so that it can be more equally shared between couples. } \\
\text { Increase the parental/maternity leave in general, and ensure a reduced percentage of employment } \\
\text { after parental leave. }\end{array}$ \\
\hline 9 & $\begin{array}{l}\text { Longer maternal and much longer paternal leave. Official support and encouragement for part-time } \\
\text { positions. Transparent accounting for time for parenting when assessing career achievements. } \\
\text { Positive attitude of bosses towards employees becoming parents. }\end{array}$ \\
\hline 10 & $\begin{array}{l}\text { It should be easier for the parents / more accepted in general to work } 50-80 \% \text { for a year or so after } \\
\text { the baby is born. }\end{array}$ \\
\hline 11 & $\begin{array}{l}\text { For active parents, it is necessary that meetings are early in the day. Work needs to be flexible to } \\
\text { some extent (I have that privilege, but it depends a lot on your professor). }\end{array}$ \\
\hline
\end{tabular}


Table 4. Cont.

\begin{tabular}{|c|c|}
\hline Number & Response \\
\hline 12 & $\begin{array}{l}\text { More and affordable day care centers, so that everyone gets a place who needs one. A longer } \\
\text { maternity break of six months would also help. }\end{array}$ \\
\hline 13 & More child care options. \\
\hline 14 & Offer child care. \\
\hline 15 & $\begin{array}{l}\text { I find it strange that there are so few day care spaces ("Krippenplätze") offered by ETH. A real } \\
\text { problem in my eyes. }\end{array}$ \\
\hline 16 & $\begin{array}{l}\text { Fair handling of ETH day care (more focus on socioeconomic aspects; seems to be for professors } \\
\text { primarily and the "lucky ones"). }\end{array}$ \\
\hline 17 & $\begin{array}{l}\text { We would have profited from a system where you can bring your children to daycare *when } \\
\text { needed* (e.g., when I was travelling), but the system was either full package day care or no day care } \\
\text { at all. This does not help if partner is * } \text { not* a scientist. }^{*}\end{array}$ \\
\hline 18 & $\begin{array}{l}\text { I don't know if D-USYS could do something in particular. But the child care system in Switzerland } \\
\text { makes it quite prohibitive to combine. }\end{array}$ \\
\hline 19 & $\begin{array}{l}\text { Clearer career options for technical/IT employees (or positions in-between research and technical } \\
\text { support). }\end{array}$ \\
\hline 20 & More security \\
\hline 21 & Permanent Mittelbau positions \\
\hline 22 & Offer potential hiring for spouses of senior staff as well, not just professors. \\
\hline \multicolumn{2}{|r|}{$\begin{array}{l}1 \text { All answers are listed; } 22 \text { participants provided a response. }{ }^{2} \text { According to the personnel laws of the ETH domain } \\
\text { [56]: "1. Female employees are entitled to four months' full pay during maternity leave. } 2 \text {. Maternity leave may } \\
\text { commence, upon the employee's request, one month prior to the expected birth. } 3 \text {. The second half of the maternity } \\
\text { leave may, after consultation with the competent instance, be taken in the form of a reduction of the contractually } \\
\text { agreed activity rate. If the father also works in the ETH domain, the parents can share this suspension of work } \\
\text { (Article 37.1-3)". This means that splitting the second half of parental leave time between the mother and father is } \\
\text { (only) possible if both parents work in the ETH domain, which includes ETH Zurich, École Polytechnique Fédérale } \\
\text { de Lausanne (EPFL), Paul Scherrer Institute (PSI), Swiss Federal Institute for Forest, Snow and Landscape Research } \\
\text { (WSL), Swiss Federal Institute of Materials Science and Technology (Empa), and the Swiss Federal Institute of } \\
\text { Aquatic Science and Technology (Eawag). In addition, } 10 \text { days of paid paternity leave are granted to workers within } \\
\text { the ETH domain who are becoming fathers (Article 52). }\end{array}$} \\
\hline
\end{tabular}

\section{Discussion}

This study asked academic employees of D-USYS at ETH about their experiences, perceptions and judgements concerning the actualisation of equal career opportunities considering ethnic, racial, nationality, religious, and gender aspects, the compatibility of work and family, as well as age-related aspects. About $90 \%$ of participants perceived "no" or "rather no" disadvantages based on ethnic, racial, religious, and gender aspects. However, whereas the respective share amongst male participants is nearly $100 \%$ perfect, at $76.6 \%$, it is substantially lower among women, which raises some concern.

The specific comments in this regard revealed not a single indication of any discrimination with relation to religious aspects. There were also very few-in total only two-comments reflecting the perception of disadvantages connected to ethnic or nationality-based aspects (Table $1, \# 5$, \#6). Accordingly, there were no substantial indications of major problems in that regard. Instead, the outcome of the survey reflects a positive image of D-USYS as an enlightened internationally oriented university department. This reassuring interpretation is also supported by a few comments stating that D-USYS is a very open-minded environment, which is quite fair on such issues.

However, there were eight comments describing the perception of gender-based discrimination (Table $1, \# 1$ to $\# 8$, i.e., about $10 \%$ of all respondents and $61 \%$ of those adding a free response). Five of these comments refer to gender-based discrimination as such (\#1,\#3,\#5, \#6, \#8). Here, two aspects already reported in previous literature, namely negative prejudice on women and better working conditions for men $[12,27,28,30,31]$ are addressed, but only by one response each. In addition, four comments address a lack of compatibility between career perspectives and family life, and are hence 
indirectly related to gender imbalances $(\# 1, \# 2, \# 4, \# 7)$. These latter imbalances are further substantiated by comments on age-related disadvantages and suggestions for improving the compatibility of work and family life. These responses can be related to the leaky pipeline and must be taken seriously. It also needs to be acknowledged in this regard that further gender-oriented cognitions of the participants may possibly have been cognitively suppressed by unconscious processes, as they do not fit with the prevailing masculine-dominated conception of the academic world as rational, according to Raewyn Connell's theory of masculinity [57,58]. Jewkes et al. [59] thus argued that in masculine-dominated contexts, "discussions of gendered power often need to be approached indirectly, lest resistance is encountered to processes that may be variously seen as outrageous in questioning men's power, or ridiculous, where men's power is 'taken for granted'" (p. 117). Although negative consequences for the expression of critique were excluded for our participants through the guaranteed anonymity of the survey, unconscious cognitive repression processes could be operative here according to Connell's theory. The orientation of ETH Zurich towards the rational subjects of science and technology and its high prestige as a scientific higher education institution may be aspects that strengthen the psychological tendencies preventing the perception of unjustified gender inequalities. The impact of gender and family aspects on career opportunities may thus be underestimated by members of ETH Zurich and of other higher education institutions.

The perceived disadvantages based on biological and/or academic age were quite prevalent, with about 30\% "yes" responses. These perceived age-related disadvantages appear to be unrelated to experiences within the direct working environment, such as personal relationships to superiors or peers within the professorships or institutes of D-USYS. Instead, all of the detailed explanations of age-based disadvantages refer to formally institutionalised rules defined at the university or federal levels. Rules defined at these superior levels hinder people who surpassed a certain age to acquire certain positions or limit the duration of staying in certain academic positions at ETH Zurich. Notably, the age limit of 35 years as an eligibility threshold for applications to become an assistant professor was mentioned frequently, even though the rule entails exceptions (e.g., regarding parenthood) [45]. The six-year rules defining the maximum duration of limited professional engagements as $\mathrm{PhD} /$ postdoc-level scientists, and/or as senior scientific assistants [44] were also frequently criticized. The shortage of open-ended senior scientist positions may have amplified this critique, as it greatly limits the chances of transcending to a fixed position after the completion of these 12 years (six years $\mathrm{PhD} /$ postdoc plus six years senior scientist). Furthermore, some research experience outside of ETH Zurich is usually expected in order to achieve permanent employment. The shortage of permanent scientific positions is not limited to ETH Zurich, and some experts thus argue for more such positions and more tenure track assistant professorships at Swiss universities in general $[47,48]$.

Some comments describing the gender-based disadvantages of women were related to time-based rules, turning the latter into a gender sensitive issue. For example, after taking maternity leave, female academics often prefer working part-time in order to have more time for taking care of their small children. Therefore, they have less time to spend on professional scientific work than scientists without children. The two sequential six-year rules, which do not compensate for parental leave times or part-time work periods, thus lower their chance to reach the academic record that is required for acquiring an assistant or a full professorship at universities worldwide. Corresponding disadvantages for academics with children are partly compensated at ETH Zurich by granting exceptions from the 35-year age limit for applicants on assistant professorships [45]. However, the comments of a number of scientists with young children indicate that these exceptions are felt to be insufficient to provide equal opportunities. Age and time-based restrictions for certain positions may thus help to explain why in particular the birth of a child after the doctorate adds to the leaky pipeline [19]. Previous studies have shown that female scientists have on average a somewhat lower publication rate as compared to males [60], need more time to advance in their career [61], and often have to cope with both children and career [43]. These and possibly further aspects make females particularly vulnerable to the excluding effects of age barriers. 
It is clear that young mothers (and fathers) who are working in science have to balance the responsibility for their children with their career ambitions, and cannot devote themselves fully to both. Various suggestions for improving the career opportunities of scientists with children favoured a revision of time limits in ways that discount for maternity leave time and adjust for phases of part-time employment.

When formal age and time limitations for scientific positions combine with gender issues, micromechanisms are created that contribute to the leaky pipeline problem.

Various links between gender issues and age related disadvantages due to formal institutionalised rules-as explained by several participants of the survey-add a new perspective to the discussion of gender-specific issues of age discrimination, which has so far focussed to a large extent on prejudice, gender roles, and gender-sensitive collective ideals and expectations of youth, beauty, and effectiveness [33-36].

Several participants wished for the provision of more child care places, more acceptance of and possibilities for part-time employment, or the introduction of partner hire recruitment on the senior scientist level, and not only when hiring professors to promote equal opportunities. ETH Zurich recently undertook great efforts to provide excellent and affordable child care services by increasing the number of available places by about $30 \%$ in the year following this survey [62]. Furthermore, ETH Zurich now facilitates the flexible time management of scientific personnel through allowing e.g., for official home office arrangements between employees and their superiors [63]. Nevertheless, generally, there still is a need for additional measures to be taken within the Swiss academic system to better support young researchers with families [14,48].

Time limits are generally advantageous for people who are able to focus "totally" on science, and proceed with their scientific work on the fast lane. Thus, the existing age limits may pose disadvantages to society as a whole, since they may hinder researchers from leading a socially more active and responsible life (e.g., raising children, engaging socially and politically). Age limits for applicants to professorship positions have also been criticised because they give age aspects priority over scientific excellence, experience, and expertise. These and similar age-based restrictions may inhibit sustainable societal development, since they can cause injustice by denying equitable access to valuable positions, and because they may hinder young researchers from combining their scientific career with social or environmental engagement. Such age-based restrictions and inequalities are by no means confined to Switzerland. The same is true for the interrelationships between formal employment restrictions based on biological or academic age and compatibility between career and family life. Furthermore, it needs to be considered in this regard that apart from the public academic sector, similar processes linking formal or informal age barriers to gender and family aspects may also exist and produce inequalities in the private sector and in non-academic public institutions. Therefore, the findings of this study are of general importance for sustainable development, as their meaning goes beyond the specific institution and country where it was conducted.

Author Contributions: R.H. and D.S. designed and conducted the survey, analyzed the data and wrote the paper. D.S. had the lead in the design of the survey. R.H. had the lead in writing the paper.

Funding: This research received no external funding.

Acknowledgments: We thank Doris Guhl (ETH Zurich Institutional Research), Nina Buchmann, Peter Frischknecht and Tom Peter (D-USYS), Cornelia Kutasi and Lukas Vonesch (ETH Zurich Human Resources), and Renate Schubert (ETH Zurich Equal!) for valuable comments on former versions of this manuscript.

Conflicts of Interest: The authors declare no conflict of interest.

\section{References}

1. World Commission on Environment and Development (WCED). Our Common Future (Brundtland Report); Oxford University Press: Oxford, UK, 1987.

2. Adomssent, M.; Godemann, J.; Michelsen, G. Transferability of approaches to sustainable development at universities as a challenge. Int. J. Sustain. High. Educ. 2007, 8, 385-402. [CrossRef] 
3. Hansmann, R. Sustainability learning: An introduction to the concept and its motivational aspects. Sustainability 2010, 2, 2873-2897. [CrossRef]

4. United Nations Educational, Scientific and Cultural Organization (UNESCO). Education for Sustainability, from Rio to Johannesburg: Lessons Learnt from a Decade of Commitment; UNESCO: Paris, France, 2002.

5. United Nations Educational, Scientific and Cultural Organization (UNESCO). World Atlas of Gender Equality in Education; UNESCO: Paris, France, 2012.

6. Velazquez, L.; Munguia, N.; Platt, A.; Taddei, J. Sustainable University: What can be the matter? J. Clean. Prod. 2006, 14, 810-819. [CrossRef]

7. Aiston, S.; Jung, J. Women academics and research productivity an international comparison. Gend. Educ. 2015, 27, 205-220. [CrossRef]

8. Austin, H.M. Women in education, science and leadership in New Zealand: A personal reflection. Stud. High. Educ. 2016, 41, 914-919. [CrossRef]

9. Davies, C.; Healey, R. Hacking through the Gordian Knot: Can facilitating operational mentoring untangle the gender research productivity puzzle in higher education? Stud. High. Educ. 2017. (published online first). [CrossRef]

10. European Commission. Strategy for Equality between Women and Men 2010-2015. European Commission Strategy adopted in September 2010; Publications Office of the European Union: Luxembourg, 2011. [CrossRef]

11. Larivière, V.; Ni, C.; Gingras, Y.; Cronin, B.; Sugimoto, C.R. Global gender disparities in science. Nature 2013, 405, 211-213. [CrossRef]

12. Shen, H. Mind the gender gap. Nature 2013, 495, 22-24. [CrossRef] [PubMed]

13. Schweizerische Universitätskonferenz (SUK + CUS). Bundesprogramm «Chancengleichheit» 2000-2003 [Federal Equality of Opportunities Program 2000-2003]; SUK CUS: Bern, Switzerland, 2002.

14. Swiss Universities. Bundesprogramm Chancengleichheit 2000-2012 [Federal Equality of Opportunities Program 2000-2012]; Swiss Universities: Bern, Switzerland, 2016.

15. Dubach, P.; Graf, I.; Stutz, H.; Gariol, L. Evaluation Bundesprogramm Chancengleichheit von Frau und Mann an den Universitäten 3. Phase 2008-2011 [Evaluation of the Third Phase of the Swiss Federal Equal Opportunity at Universities Programme (2008-2011/2012)]; SERI: Bern, Switzerland, 2012.

16. Swiss Universities. Bundesprogramm Chancengleichheit 2008-2012/13 Modul 1: Professorinnen [Federal Equality of Opportunities Program 2008-2012/13 Module 1 Female Professors]; Swiss Universities: Bern, Switzerland, 2013.

17. Swiss Universities. SUK-Teilprogramm P-4 Chancengleichheit TPC 2013-2016 Professorinnen [SUK-Subprogramme P-4 Equality Opportunities 2013-2016]; Swiss Universities: Bern, Switzerland, 2015.

18. Schmits, A. Werden die Eltern gut betreut, sind es auch die Kinder [If parents are cared for well, so are the children]. ETH Life 2014, 12, 13.

19. Leemann, R.J.; Dubach, P.; Boes, S. The leaky pipeline in the Swiss university system: Identifying gender barriers in postgraduate education and networks using longitudinal data. Swiss J. Sociol. 2010, 36, 299-323.

20. Bundesamt für Statistik (BFS) [Federal Statistical Office Switzerland]. Ausgewählte Bildungsabschlüsse. Entwicklung Dargestellter Zeitraum: 1980-2017 [Selected Educational Qualifications. Development of the Period 1980-2017]; BFS: Neuchâtel, Switzerland, 2018.

21. Dubach, P.; Legler, V.; Morger, M.; Stutz, H. Frauen und Männer an Schweizer Hochschulen: Indikatoren zur Chancengleichheit in Studium und Wissenschaftlicher Laufbahn [Women and Men at Swiss Universities: Indicators on Equal Opportunities in Studies and Academic Careers]; Staatssekretariat für Bildung, Forschung und Innovation (SBFI): Bern, Switzerland, 2017.

22. European Commission. Mapping the Maze: Getting More Women to the Top in Research; Publications Office of the European Union: Luxembourg, 2008.

23. Schubert, R.; Kaczykowski-Patermann, H. Gender Monitoring 2016/17: Report on the Gender Balance between Women and Men in Studies and Research at ETH Zurich; ETH Zurich Equal! (Office of Equal Opportunities for Women and Men): Zurich, Switzerland, 2017.

24. ETH Zurich Equal! (Office of Equal Opportunities for Women and Men). Gender Monitoring 2015/16, Department Report: Environmental Systems Science; ETH Zurich Equal! (Office of Equal Opportunities for Women and Men): Zurich, Switzerland, 2016.

25. Nikunen, M. Changing university work, freedom, flexibility and family. Stud. High. Educ. 2012, 37, 713-729. [CrossRef] 
26. Wunsch, M.A. Mentoring probationary women academics: A pilot programme for career development. Stud. High. Educ. 1993, 18, 349-362. [CrossRef]

27. Sarsons, H. Recognition for Group Work: Gender Differences in Academia. Am. Econ. Rev. 2017, 107, 141-145. [CrossRef]

28. Tiainen, T.; Berki, E. The re-production process of gender bias: A case of ICT professors through recruitment in a gender-neutral country. Stud. High. Educ. 2017. (published online first). [CrossRef]

29. Wolfers, J. When Team-Work Doesn't Work for Women. The New York Times. 8 January 2016. Available online: http:/ / www.nytimes.com/2016/01/10/upshot/when-team-work-doesnt-work-for-women.html (accessed on 20 May 2017).

30. Bailyn, L. Academic careers and gender equity: Lessons learned from MIT. Gend. Work Organ. 2003, 10, 137-153. [CrossRef]

31. Knights, D.; Richards, W. Sex discrimination in UK academia. Gend. Work Organ. 2003, 10, $213-238$. [CrossRef]

32. Guarino, C.M.; Borden, V.M.H. Faculty Service Loads and Gender: Are Women Taking Care of the Academic Family? Res. High. Educ. 2017, 58, 672-694. [CrossRef]

33. Angervall, P.; Beach, D. Dividing academic work: Gender and academic career at Swedish universities. Gender Educ. 2017. (published online first). [CrossRef]

34. Granleese, J.; Sayer, G. Gendered ageism and 'lookism': A triple jeopardy for female academics. Women Manag. Rev. 2006, 21, 500-517. [CrossRef]

35. Jyrkinen, M. Women managers, careers and gendered ageism. Scand. J. Manag. 2014, 30, 175-185. [CrossRef]

36. Jyrkinen, M.; McKie, L. Gender, age and ageism: Experiences of women managers in Finland and Scotland. Work Employ. Soc. 2012, 26, 61-77. [CrossRef]

37. Ojala, H.; Pietilä, I.; Nikander, P. Immune to ageism? Men's perceptions of age-based discrimination in everyday contexts. J. Aging Stud. 2016, 39, 44-53. [CrossRef] [PubMed]

38. Nelson, T.D. (Ed.) Ageism: Stereotyping and Prejudice against Older Persons; Massachusetts Institute of Technology: Cambridge, MA, USA, 2002.

39. Grossman, R.J. The under-reported impact of age discrimination and its threat to business vitality. Bus. Horiz. 2005, 48, 71-78. [CrossRef]

40. Archer, L. Younger academics' constructions of 'authenticity', 'success' and professional identity. Stud. High. Educ. 2008, 33, 385-403. [CrossRef]

41. Leathwood, C.; Francis, B. Gender and Lifelong Learning; Routledge: London, UK, 2006.

42. Monroe, K.; Ozyurt, S.; Wrigley, T.; Alexander, A. Gender equality in academia: Bad news from the trenches, and some possible solutions. Perspect. Politics 2008, 6, 215-233. [CrossRef]

43. Acker, S.; Armenti, C. Sleepless in academia. Gend. Educ. 2004, 16, 3-24. [CrossRef]

44. ETH Zurich. Ordinance Governing Scientific Employees of the Swiss Federal Institute of Technology Zurich (Date: 16 September 2014); ETH Zurich: Zurich, Switzerland, 2014.

45. ETH Zurich. Richtlinien des Präsidenten über das Assistenzprofessuren-System an der ETH Zürich (vom 1 February 2015) (Rechtssammlung RSETHZ 510.21). [Guidelines of the President on the Assistant Professorship System at ETH Zurich (from 1 February 2015). (Collection RSETHZ 510.21)]; ETH Zurich: Zurich, Switzerland, 2015.

46. Battegay, C. Chancen für Postdocs? Chancen für die Wissenschaft! [Chances for postdocs? Chances for science!]. Swiss Acad. Hum. Soc. Sci. Bull. 2017, 3, 51-52.

47. Epiney, A. Universitäre «Karrierewege»: Für eine Diversifizierung der Stellenstruktur [University careers: For a diversification of positions]. Swiss Acad. Hum. Soc. Sci. Bull. 2017, 3, 45-46.

48. Hirschi, C. Vision 2020-Eine Bilanz nach fünf Jahren [Vision 2020-A review after five years]. Swiss Acad. Hum. Soc. Sci. Bull. 2017, 3, 39-40.

49. Preissler, U.; Detmer, H. Einstellungsaltersgrenzen für Professoren-Eine Länderübersicht [Hiring Age Limits for Professors-An Overview of Countries]. 2010. Available online: https:/ /www.academics.de/ wissenschaft/einstellungsaltersgrenzen_fuer_professoren_-_eine_laenderuebersicht_37406.html (accessed on 4 January 2017).

50. Hill, R.D.; Castillo, L.G.; Ngu, L.Q.; Pepion, K. Mentoring ethnic minority students for careers in academia: The WICHE Doctoral Scholars Program. Couns. Psychol. 1999, 27, 827-845. [CrossRef]

51. Turner, C.S.V.; González, J.C.; Wood, J.L. Faculty of color in academe: What 20 years of literature tells us. J. Divers. High. Educ. 2008, 1, 139-168. [CrossRef] 
52. Hansmann, R.; Jödicke, A.; Brändle, U.; Guhl, D.; Frischknecht, P. How the Bologna reform influenced learning outcomes: Analysis of perceived qualifications and professional requirements of environmental sciences graduates. Stud. High. Educ. 2017. (published online first). [CrossRef]

53. Mieg, H.A.; Hansmann, R.; Frischknecht, P.M. National sustainability outreach assessment based on human and social capital: The case of Environmental Sciences in Switzerland. Sustainability 2012, 4, 17-41. [CrossRef]

54. Bundesamt für Statistik (BFS) [Federal Statistical Office Switzerland]. Personal der Universitären Hochschulen 2010 [Personnel of Universities 2010]; BFS: Neuchâtel, Switzerland, 2011.

55. ETH Zurich. Strategie und Entwicklungsplan 2017-2020 [Strategy and Development Plan 2017-2020]; ETH Zurich: Zurich, Switzerland, 2016.

56. ETH Board [Board of the Swiss Federal Institutes of Technology]. Personnel Law. Ordinance of the ETH Board Concerning Personnel in the Swiss Federal Institutes of Technology Domain; ETH Board: Zurich, Switzerland, 2018.

57. Connell, R. Gender and Power: Society, the Person and Sexual Politics; University of California Press: Palo Alta, CA, USA, 1987.

58. Connell, R. Masculinities in global perspective: Hegemony, contestation, and changing structures of power. Theor. Soc. 2016, 45, 303-318. [CrossRef]

59. Jewkes, R.; Morrell, R.; Hearn, J.; Lundqvist, E.; Blackbeard, D.; Lindegger, G.; Quayle, M.; Sikweyiya, Y.; Gottzéni, L. Hegemonic masculinity: Combining theory and practice in gender Intervention. Cult. Health Sex. 2015, 17, 112-127. [CrossRef] [PubMed]

60. Rørstad, K.; Aksnes, D.W. Publication rate expressed by age, gender and academic position-A large-scale analysis of Norwegian academic staff. J. Inform. 2015, 9, 317-333. [CrossRef]

61. Van den Besselaar, P.; Sandström, U. Gender differences in research performance and its impact on careers: A longitudinal case study. Scientometrics 2016, 106, 143-162. [CrossRef] [PubMed]

62. Schmits, A. Mehr Plätze für die Kleinen [More places for the small people]. ETH Life 2016, 1, 13.

63. ETH Zurich Human Resources. Regelmässiges Home Office für Mitarbeitende der ETH Zürich. Merkblatt [Regular Home Office for Staff of ETH Zurich. Information]; ETH Zurich Human Resources: Zurich, Switzerland, 2016.

(C) 2018 by the authors. Licensee MDPI, Basel, Switzerland. This article is an open access article distributed under the terms and conditions of the Creative Commons Attribution (CC BY) license (http:/ / creativecommons.org/licenses/by/4.0/). 